\title{
Topics
}

Bariş K. Yörük*

\section{Do Charitable Subsidies Crowd Out Political Giving? The Missing Link between Charitable and Political Contributions}

\begin{abstract}
In the United States, charitable contributions can be deducted from taxable income making the price of giving inversely related to the marginal tax rate. However, several other types of contributions such as donations to political organizations are not tax deductible. This paper investigates the spillover effects of charitable subsidies on political giving using five cross-sectional surveys of charitable and political giving in the United States conducted from 1990 to 2001. The results show that charitable and political giving are complements. Compared with non-donors, charitable donors are more likely to donate and give more to political organizations. Increasing the price of charitable giving decreases not only charitable giving but also the probability of giving and the amount of donations to political organizations. This effect is robust under different specifications and highlights the externalities created by charitable subsidies.
\end{abstract}

Keywords: charitable giving, political giving, tax price of giving JEL Classification: H24, H31, L38

\section{Introduction}

In the United States and several other countries, charitable contributions are tax deductible. This makes a charitable donation less costly for those who itemize deductions in their federal or state income tax returns. According to the most recent estimate, the federal government was estimated to have $\$ 37.6$ billion in foregone revenue in 2012 due to millions of households who itemized charitable

*Corresponding author: Bariş K. Yörük, Department of Economics, University at Albany-SUNY, 1400 Washington Ave., Albany, NY 12222, USA, E-mail: byoruk@albany.edu 
deductions in their federal tax returns (Joint Committee on Taxation 2013). The economic rationales for providing tax subsidies for charitable contributions are well-documented in the literature. ${ }^{1}$ Recent literature also documents that the amount of charitable contributions are very responsive to tax subsidies. ${ }^{2}$ However, the indirect effects of charitable subsidies on other types of contributions, in particular on those that are not tax deductible, remain unknown. In this paper, using data from five cross-sectional surveys of charitable and political giving in the United States conducted from 1990 to 2001, I investigate the relationship between charitable giving and another type of contribution that is not tax deductible, namely political giving. This paper also investigates the spillover effects of charitable subsidies on the propensity to give and the amount of donations to political organizations.

The relationship between charitable and political giving is ambiguous. Assuming that charitable and political contributions are normal goods, a simple economic intuition suggests that an individual with a limited portion of her income to allocate between political and charitable organizations should make her decision depending on her preferences and the prices of these two goods. If charitable and political giving are substitutes, then an increase in the price of one of these goods should increase the demand for the other. In this case, charitable subsidies should make charitable contributions more attractive by decreasing their effective price, but at the same time, should negatively affect political contributions. On the other hand, charitable and political donations are two examples of prosocial behavior, which are defined as actions that benefit other people or society as a whole (Twenge et al. 2007). Another important form of prosocial behavior is expressing opinions about political or social issues. People contribute to certain charitable organizations because they are sympathetic to the causes supported by these organizations. People may also express their opinions about social or political issues through voting or giving to political organizations. If the major motivation behind charitable and political

1 In particular, nonprofit organizations are useful institutions for correcting private market failures (Roberts 1987; Saez 2004). Nonprofit organizations also offer a mechanism whereby individuals are able to satisfy demands for public goods that are unmet by the public sector (Weisbrod 1988) and provide a forum in which individuals can advocate for particular public policies (Ferris 1998).

2 Recent studies that investigate the impact of tax subsidies on charitable giving include Clotfelter (1990), Randolph (1995), and Auten, Sieg, and Clotfelter (2002). Andreoni (2006) also provides an extensive discussion of the relationship between tax subsidies and giving. The elasticities in the literature are as low as -0.5 but in general are greater than -1 . Therefore, a $1 \%$ increase in tax subsidies for charitable giving would lead to more than $1 \%$ increase in the amount of charitable contributions. 
giving is prosocial behavior, then these two different types of giving may be economic complements. If charitable and political giving are complements, then a subsidy for charitable giving, i.e. decreasing its tax price, should increase both charitable and political contributions. Finally, depending on preferences, demand for each of these goods can be independent from the price of the other good. If this is the case, a charitable subsidy should positively affect charitable giving while political contributions remain unaffected.

A large body of literature in economics and political science is dedicated to understand the determinants of political behavior. ${ }^{3}$ Joulfaian and Marlow (1991) document that several demographic variables such as age, wealth, and marital status are positively associated with the propensity to donate to a political organization. In addition to standard demographic variables, recent literature also argues that political interest and opinions, alternative forms of expressive behavior, ability, and various measures of personality are also significant determinants of political behavior. For instance, using a bivariate probit model of voter turnout and political interest, Denny and Doyle (2008) find that individuals with high comprehension ability and an aggressive personality are more likely to vote and have an interest in politics. Similarly, Copeland and Laband (2002) show that voting is positively associated with other forms of expressive behavior, such as putting a political bumper sticker on one's car. Amaro-deMatos and Barros (2004) develop a model in which social norms and networks significantly affect the voter turnout rate.

Most of the papers that investigate the relationship between charitable giving and other types of prosocial behavior focus on jointly modeling charitable contributions of time and money. Menchik and Weisbrod (1987), Brown and Lankford (1992), and Andreoni, Gale, and Scholz (1996) find that time and money are complements and hence, charitable subsidies should not only increase charitable giving but also volunteering as well. ${ }^{4}$ Furthermore, few papers explore the relationship between generosity and religious behavior. Sullivan (1985) and Yörük (2013) find that these two behaviors are complements, whereas Gruber (2004) finds that religious giving and religious attendance are

3 In this paper, I focus on households' contributions to political organizations. A vast majority of the existing studies focus on the determinants of corporate political contributions. See, for example, Cooper, Gulen, and Ovtchinnikov (2010), de Figueiredo and Edwards (2007), and Abler (1991).

4 In contrast. Feldman (2010) finds that donations of time and money are substitutes. However, a decrease in the tax price of monetary contributions has a positive effect on contributions of time that acts outside the change in relative prices and more than offsets the substitution effect leading to an overall positive correlation between these two charitable goods. 
substitutes. However, the relationship between charitable behavior and other types of contributions and prosocial behavior remains unknown.

In this paper, I investigate the relationship between charitable and political giving. Understanding the relationship between charitable and political giving may reveal a previously unknown determinant of political contributions. On the other hand, a possible relationship between these two prosocial behaviors may help policymakers to make informed choices about the indirect effects of tax subsidies for charitable giving. This is particularly important for shaping future tax policies.

In order to investigate the relationship between charitable and political giving, I use five cross-sectional surveys, which contain information on households' donations to political organizations. I hypothesize that some unobservable variables should jointly affect charitable and political giving. Therefore, one must address the possible endogeneity of charitable behavior in political giving models. Since political contributions are not tax deductible, I use the tax price of giving as a main identifying instrument for charitable behavior. ${ }^{5}$ I expect that the tax price should be negatively correlated with charitable contributions but uncorrelated with the unobserved variables that may affect political giving.

After controlling for the endogeneity of the amount of charitable contributions, I find that compared with non-donors, charitable donors are on average 7.4-8.1 percentage points more likely to donate to political organizations. Moreover, charitable donors donate more to political organizations compared with their non-donor peers even after income and other observable household characteristics are controlled for. I also find a positive relationship between the amount of gifts donated to charitable and political organizations. A one dollar increase in charitable contributions increases political contributions by 0.15 dollars. Furthermore, the relationship between charitable and political giving is robust under alternative specifications.

These results imply that charitable and political giving are complements. Increasing the tax price of giving decreases charitable contributions but at the same time, negatively affects the amount of donations and the probability of giving to political organizations. I estimate that at the $36 \%$ tax bracket, the implied cross-price elasticity of the amount of political contributions with respect to the tax price is -0.89 . However, when the tax price is unity, a one percentage point increase in the tax price corresponds to a $0.74 \%$ decrease in the amount of political contributions. On the other hand, the predicted probability of giving to political organizations goes down as the tax price of charitable giving increases.

5 Gruber (2004) follows a similar approach to identify the effect of tax price of giving on religious attendance. 
The rest of this paper is organized as follows. The next section presents the data and discusses the relationship between charitable and political giving. Section 3 sets out the specifications for different empirical models and discusses the validity of instrumental variables. Section 4 presents the results. Section 5 focuses on the spillover effects of charitable subsidies on political giving and provides a discussion of policy implications. Section 6 summarizes the findings and concludes.

\section{Data}

I use a rich data set of charitable giving surveys conducted in 1990, 1992, 1994, 1996, and 2001. ${ }^{6}$ The Survey of Giving and Volunteering in the United States series (SGV) are five cross-sectional surveys that obtain information on charitable and political contributions at the household level, and on various indicators of relevant motivations, household social characteristics, selected demographic descriptors, and economic factors. Weighting procedures are used to ensure that the final sample of respondents is representative of all non-institutionalized adults, 21 years of age and older. ${ }^{7}$ Pooling the cross-sectional data from 1990 to 2001 and eliminating the observations missing key variables yields a nationally representative sample of 12,065 households for the empirical analysis. ${ }^{8}$

Each survey respondent was asked about the household giving during the year before the survey for 13 separate charity categories. ${ }^{9}$ I identify the

6 The 1990, 1992, 1994, and 1996 waves of the survey series were conducted by the Gallup Organization, whereas the 2001 wave was conducted by Westat Inc. All waves were commissioned by the Independent Sector. The Independent Sector also collected data for 1988 and 1999. However, respondents of these surveys were not asked questions about their political contributions.

7 There are other sources of survey data that contain information on household giving to charitable organizations such as the Panel Study of Income Dynamics (PSID). However, to my best knowledge, the SGV is the only survey that also contains information on political contributions.

8 There are 2,727 observations in the 1990 wave, 2,671 observations in the 1992 wave, 1,509 observations in the 1994 wave, 2,719 observations in the 1996 wave, and 4,178 observations in the 2001 wave. In particular, 406 observations in the 1990 wave, 405 observations in the 1992 wave, 278 observations in the 1994 wave, 253 observations in the 1996 wave, and 397 observations in the 2001 wave were eliminated due to missing information on key variables.

9 These categories are religious organizations, youth development, education, health, human services, environment and animal welfare, adult recreation, arts, culture, and humanities, public or societal benefit, private and community foundations, international or foreign programs, and other unnamed areas. The SGV also contains information on giving to relatives and giving to friends and neighbors. This information is not used, however. 
respondent as a charitable donor if her household has given to at least one of these categories. I calculate the total amount of charitable contributions as the sum of money that the household has reported giving to each of the specific charity groups. More than $74 \%$ of the households contribute to charitable organizations and the average contribution amount is $\$ 740 .^{10}$ Alternatively, charitable donors give $3 \%$ of their income to charity. ${ }^{11}$ Since most of the charitable contributions in the United States are directed to religious organizations, when giving to this category is excluded, the probability of giving and the mean contribution amount considerably decrease. On average, 37\% of the respondents give to secular charities and the mean contribution amount to secular charities is $\$ 474$. Appendix A reports the summary statistics and further describes the key variables used in the empirical analysis in detail.

\subsection{The relationship between charitable and political contributions}

A unique feature of the SGV is that it contains information on household's contributions to political organizations for each respondent. ${ }^{12}$ The empirical analysis uses data from 1990 to 2001. During this period, three presidential elections have taken place in the United States. Bill Clinton won the presidential elections of 1992 and 1996, whereas George Bush won the presidential election of 2000. In Figure 1 panel A, I plot the probability of giving and the average amount of contributions to political organizations for each survey year. On average, $8-12 \%$ of the households have reported giving to political organizations. In general, the probability of giving to political organizations exhibits a decreasing trend between two presidential election years (1992 and 1996) and an increasing trend for the rest of the survey years. On the other hand, the amount of contributions to political organizations exhibits an increasing trend from 1990 to 1996, but decreases after the 2000 presidential elections (in 2001). The average contribution amount to

10 The amount of charitable and political contributions and household income are reported in 1996 dollars throughout the paper. The average donation amount includes those households who did not give any money to charity. The average donation amount for those who gave to charity is $\$ 1,099$.

11 These numbers are comparable to giving rates from other sources of charitable giving data such as the PSID and tax returns from the IRS. For instance, in the 2001 wave of the PSID, the giving rate is $69 \%$ and donors on average gave $3 \%$ of their income to charities.

12 The respondents were asked the following question in each wave of the survey series: "Approximately how much money or the cash equivalent of property did you and the members of your household contribute to political organizations in [survey year]?” 


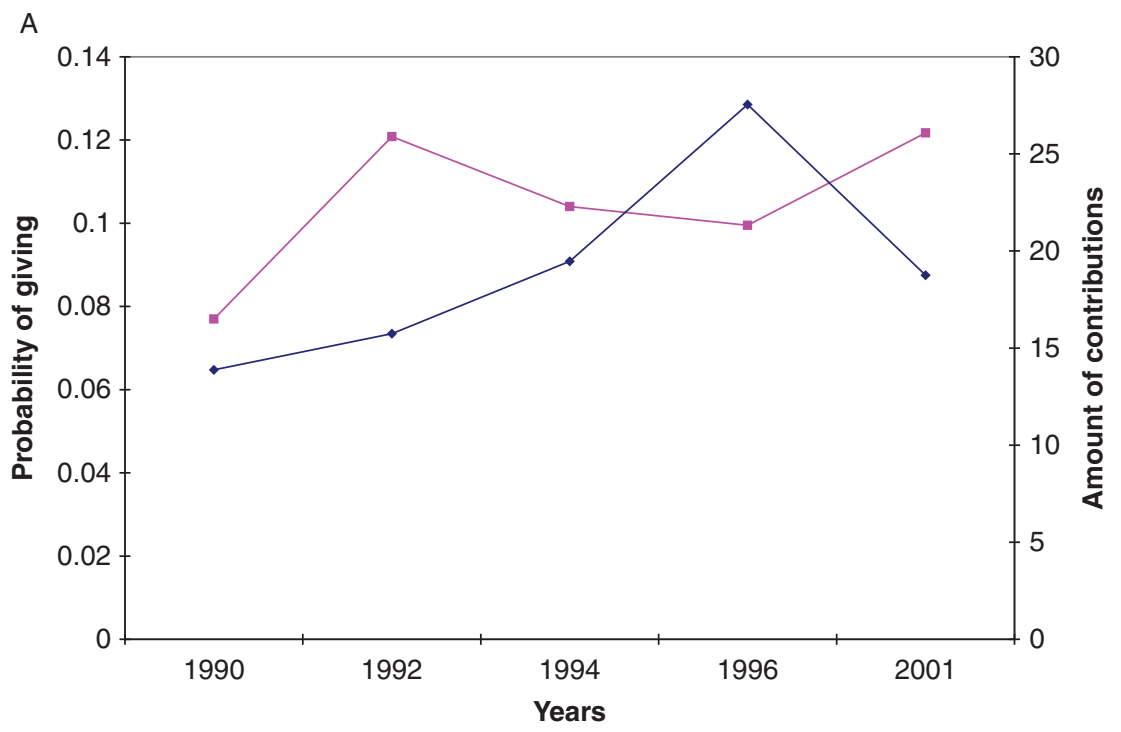

$\rightarrow-$ Probability of giving $\rightarrow$ Amount of contributions

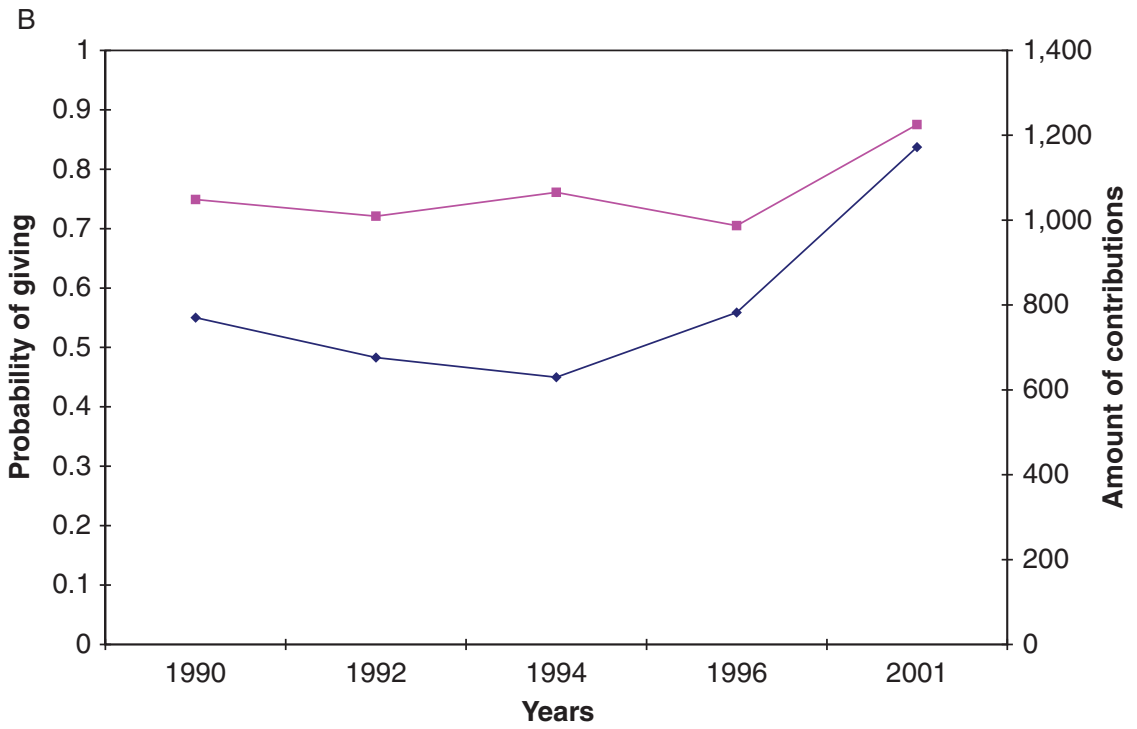

- Probability of giving $\rightarrow$ Amount of contributions

Figure 1: The probability of giving and the amount of contributions to political and charitable organizations by year. A. Political organizations. B. Charitable organizations 
political organizations differs between $\$ 14$ and $\$ 27$ across the survey years. ${ }^{13}$ Panel B of Figure 1 shows that charitable giving trends during the same time period follow a similar trend. The probability of giving to charitable organizations across the survey years differs between 0.75 and 0.87. From 1990 to 1996, the average contributions to charitable organizations differ from $\$ 630$ to $\$ 780$. However, in contrast to political giving trends, the average charitable contribution amount increases considerably in 2001. ${ }^{14}$

Table 1 further documents the close relationship between charitable and political giving. On average, charitable donors are 10 percentage points more likely to give to political organizations. This difference is statistically significant and persistent for the subsample of unmarried respondents. Furthermore, Table 1 documents that compared with non-donors, on average charitable donors give $\$ 18$ more to political organizations. Table 2 shows that non-donors not only being a

Table 1: The relationship between political giving and the decision to give to charitable organizations

\begin{tabular}{lcrr}
\hline & Give $=1$ & Give $=\mathbf{0}$ & Difference \\
\hline Probability of giving to political organizations & & \\
Full sample & 0.128 & 0.026 & 0.102 \\
& $(0.003)$ & $(0.003)$ & $(0.006)$ \\
Unmarried & 0.102 & 0.018 & 0.084 \\
& $(0.005)$ & $(0.004)$ & $(0.008)$ \\
Amount of political contributions & & \\
Full sample & 20.27 & 2.07 & 18.20 \\
& $(3.14)$ & $(0.38)$ & $(5.46)$ \\
Unmarried & 9.56 & 1.87 & 7.67 \\
& $(1.47)$ & $(0.51)$ & $(2.08)$ \\
\hline
\end{tabular}

Notes: Sample weighted means are reported. Standard errors are reported in parenthesis. "Give" is a binary variable and equals to unity if the respondent donated money to charitable organizations. Difference between the donors and non-donors is statistically significant for the full sample and for unmarried respondents.

13 On average, households donate $\$ 27$ to political organization in 1996. In this year, Bill Clinton was re-elected to serve a second term as President of the United States.

14 This finding is consistent with the historical trends in charitable giving reported by Giving USA Foundation (2003). Giving USA Foundation reports that starting from 1986, giving as percent of income had a decreasing trend until 1996, followed by an increasing trend until 2002. Furthermore, from 1989 to 1996, total amount of contributions by individuals were stable (around \$110 billion in 2002 dollars). Starting from 1996, individual giving increased tremendously and reached $\$ 185$ billion in 2001. Andreoni (2006) also discusses the historical trends in individual giving. 
Table 2: The relationship between political giving and the amount of charitable contributions

Contribution amount in 1996 dollars

Up to \$100 \$101-\$250 \$251-\$750 \$751-\$1,500 More than $\$ 1,501$

Probability of giving to political organizations

\begin{tabular}{|c|c|c|c|c|c|}
\hline \multirow[t]{2}{*}{ Full sample } & 0.068 & 0.104 & 0.170 & 0.204 & 0.265 \\
\hline & $(0.252)$ & $(0.305)$ & $(0.375)$ & $(0.403)$ & $(0.441)$ \\
\hline \multirow[t]{2}{*}{ Unmarried } & 0.049 & 0.100 & 0.123 & 0.315 & 0.205 \\
\hline & $(0.217)$ & $(0.301)$ & $(0.328)$ & $(0.465)$ & $(0.405)$ \\
\hline
\end{tabular}

Amount of political contributions

\begin{tabular}{lrrrrr} 
Full sample & 2.42 & 7.65 & 30.14 & 48.56 & 73.97 \\
& $(12.95)$ & $(52.85)$ & $(358.43)$ & $(304.14)$ & 821.97 \\
Unmarried & 2.01 & 7.58 & 7.46 & 54.03 & 42.11 \\
& $(13.33)$ & $(55.12)$ & $(28.76)$ & $(171.06)$ & $(294.43)$ \\
\hline
\end{tabular}

Notes: Sample weighted means are reported. Standard deviations are reported in patenthesis.

charitable donors but also the amount of the charitable gift is closely associated with the probability of giving and amount of contributions to political organizations. On average, $7 \%$ of the bottom quintile of charitable donors who donate up to $\$ 100$ also contribute to political organization, whereas this rate rises to $27 \%$ at the top quintile of charitable donors who give more than $\$ 1500$. The amount of gifts to charitable and political organizations is also closely linked. The bottom quintile of donors who donate up to $\$ 100$ to charitable organizations on average donate only $\$ 2$ to political organizations. At the top quintile of charitable donors, the average contribution amount to political organizations increases to $\$ 74$. A similar trend is also observed for unmarried donors. Therefore, simple tabulations reveal a positive relationship between charitable and political contributions.

\subsection{The tax price of giving}

Since households are allowed to itemize charitable deductions on their federal and most state personal income tax returns, each dollar given away to charity costs less than a dollar if the household itemizes deductions. Following the standard practice in the literature, I compute the price of giving as $1-t$ for those who itemize deductions and 1 for those who do not, where $t$ is the sum of federal and state marginal tax rates that the donor faces. ${ }^{15}$

15 See, for example, Duncan (1999), Andreoni, Brown, and Rischall (2003), Yörük (2009), and Yörük (2010). 
The SGV contains a question which obtains information on whether the respondent itemized deductions or not. In order to calculate the marginal tax rates for each individual at a given year, I use National Bureau of Economic Research (NBER)'s TAXSIM model (version 9.0). ${ }^{16}$ This model inputs information on household income, state of residence, marital status, number of children, age, child care expenses, and itemized deductions such as charitable donations, health care expenses, mortgage interest payments, and property taxes or rent paid and outputs federal and state marginal tax rates for each individual. ${ }^{17}$

As Gruber (2004) points out, the resulting after-tax prices of giving vary across the respondents primarily due to the differences in income, state of residence, and time. There have been several changes in the schedule of tax rates from 1990 to 2001 at the federal level, which are incorporated into the calculation of the marginal tax rates. For instance, in 1992, the tax rate of 33\% was reduced to $31 \%$, in 1994 , new tax rates of $36 \%$ and $39.6 \%$ were introduced, in 2001, tax rates higher than $15 \%$ were reduced by 0.5 percentage points. There is also a considerable amount of variation in the marginal tax rates based on households' state of residence due to changes in the schedule of income tax rates at the state level during the same period. Furthermore, several states do not allow a deduction for charitable contributions. Therefore, tax policy changes at the federal and state level from 1990 to 2001 create a considerable amount of variation in the tax price in order to identify the relationship between charitable and political giving. Income, time, and state of residence may also be correlated with charitable and political giving. In addition to several other demographic variables, the empirical models explicitly control for the effects of these variables on charitable and political giving.

\section{Empirical models}

In this section, I investigate the relationship between four outcomes. These are the probability of giving and the amount contributions to charitable and political organizations. The empirical models that I consider address for the endogeneity of charitable behavior since some unobservable factors which may affect

16 The TAXSIM model is available at http://www.nber.org/126taxsim/taxsim-calc9/index.html. 17 Following the previous literature, I assume that those who are married declare joint filing status. For those who itemize deductions, following Andreoni, Gale, and Scholz (1996), I assign the average level of itemized deductions from the IRS tax return data for the relevant survey year, conditioning on filing status and income. Following Gruber (2004), I use total family income instead of using separate incomes for heads and wives. 
charitable giving may also be correlated with political giving. ${ }^{18}$ The magnitude and direction of the effect that can be attributed to the endogeneity problem is ambiguous, however. If charitably inclined people are also those who are more likely to give to political organizations, then one expects that unobservable factors that affect charitable giving should be positively correlated with unobservables affecting political giving. In this case, not controlling for the endogeneity of charitable giving should overestimate the true effect of charitable behavior on political giving. However, if some unobservable factors that may be positively associated with political giving are negatively associated with charitable giving, then not controlling for the endogeneity problem in political giving models should underestimate the true effect of charitable behavior on political giving. Finally, if unobservable factors that affect political and charitable giving are uncorrelated, then one should get a consistent estimate of the effect of generosity on political giving without controlling for the possible endogeneity problem. The empirical models presented in this section not only explicitly control for the endogeneity of charitable behavior but also reveal the direction of the effect that can be attributed to this possible endogeneity problem.

\subsection{The effect of charitable behavior on the probability of political giving}

First, I consider a probit model of the probability of giving to political organizations with an endogenous binary independent variable give $e_{i, t s}$ which takes the value of unity if household $i$ residing in state $s$ donated money to charitable organizations in year $t$. For the same household, let politics ${ }_{i, t s}$ denote a binary political giving indicator which can be expressed as

$$
\text { politics }_{i, t s}=\mathbf{1}\left\{\beta_{1}^{\prime} X_{i, t s}+\alpha_{1} \text { give }_{i, t s}+\lambda_{1}^{\prime} S_{t s}+\eta_{1}^{\prime} \text { state }_{s}+\delta_{1}^{\prime} \text { year }_{t}+u_{1 i, t s} \geq 0\right\}
$$

where $\mathbf{1}($.$) denotes the indicator function, X_{i, t s}$ is a covariate vector of income and other observable characteristics of the household $i$ such as family size and number of children in the household, $S_{t s}$ is a set of state-level control variables, state $_{s}$ and year ${ }_{t}$ are vectors of state and year fixed effects, and $u_{1 i, t s}$ is a normally

18 Due to the limitations of data, empirical models cannot control for several variables that may affect both charitable and political giving. For instance, health status, political views, wealth, and cultural background of household members may simultaneously affect households' contributions to charitable and political organizations. Since the data set does not contain any information on these variables, these variables are included in empirical models as a part of the error term (unobservable factors that may affect charitable and political contributions). 
distributed random error with zero mean and unit variance. ${ }^{19}$ Gruber and Saez (2002) argue that changes in tax policies may be causally related to changes in the pre-tax income distribution over time. Tax reforms may also affect different points in the income distribution in different ways. In order to address these problems, following Gruber (2004), I add, in addition to log of income, a 10-piece spline of household income to set of control variables. ${ }^{20}$ If unobservable factors that affect political and charitable and giving are uncorrelated, then the probability of giving is exogenous and the parameters of the above model can be estimated directly. However, if charitable behavior is endogenously determined in eq. [1], failing to take this into account results in biased parameter estimates. In order to address the endogeneity problem, I consider the following model:

$$
\text { give }_{i, t s}=\mathbf{1}\left\{\beta_{2}^{\prime} X_{i, t s}+\zeta_{1} \text { price }_{i, t s}+\lambda_{2}^{\prime} S_{t s}+\eta_{2}^{\prime} \text { state }_{s}+\delta_{2}^{\prime} \text { year }_{t}+u_{2 i, t s} \geq 0\right\}
$$

where price $_{i, t s}$ is the natural logarithm of the tax price of charitable giving for individual $i$ and $u_{2 i, t}$ is a normally distributed random error with zero mean and unit variance. ${ }^{21}$ Assume that the error terms of eqs [1] and [2] are independently and identically distributed as a bivariate normal with $E\left[u_{1 i, t}\right]=E\left[u_{2 i, t}\right]=0$, $\operatorname{var}\left[u_{1 i, t}\right]=\operatorname{var}\left[u_{2 i, t}\right]=1$, and $\operatorname{cov}\left[u_{1 i, t}, u_{2 i, t}\right]=\rho$. Then, following Evans and Schwab (1995) and Wooldridge (2002), the likelihood function corresponding to this set of events can be estimated as a bivariate probit using price $e_{i, t s}$ as the identifying instrument for the probability of giving to charity. ${ }^{22}$ If $\rho \neq 0$, then

19 The following variables are controlled for at the household level: Household income, family size, and the number of children in the household. The description and summary statistics for these variables are presented in Appendix A. At the state level, I control for income per capita in 1996 prices, median age, unemployment rate, percent of females, blacks, and Hispanics in the population, and percent of high school, college, and graduate school graduates in the population. The state-level control variables are compiled from Census Bureau Estimates for each survey year. 20 These is a set of ten dummy variables controlling for different income levels. These income categories are as follows: $\$ 10,000-\$ 20,000, \$ 20,000-\$ 30,000, \$ 30,000-\$ 40,000, \$ 40,000$ $\$ 50,000, \quad \$ 50,000-\$ 60,000, \quad \$ 60,000-\$ 70,000, \quad \$ 70,000-\$ 80,000, \quad \$ 80,000-\$ 90,000$, $\$ 90,000-\$ 100,000$, and more than $\$ 100,000$. The excluded category is those households who earn less than $\$ 10,000$.

21 A widely discussed empirical issue in the literature is the endogeneity of the tax price in giving models. However, a possible endogeneity of the tax price should not affect the estimates of the political giving models as long as unobserved covariates that are jointly correlated with the tax price and charitable giving are uncorrelated with political giving. Furthermore, using the first tax price of giving which excludes charitable contributions, a widely used instrument in the literature, yields comparable estimates. These results are available from the author upon request. 22 Following Maddala (1983), it is widely believed in the literature that in the joint estimation of eqs [1] and [2], parameter vectors are not identified in the absence of exclusionary restrictions. 
$u_{1 i, t s}$ and $u_{2 i, t s}$ are correlated and running separate probit regressions for the eqs [1] and [2] yields inconsistent estimates for the parameter vectors.

In order to investigate the marginal effect of the amount of charitable contributions on the probability of giving to political organizations, I consider the following model:

$$
\text { politics }_{i, t s}=1\left\{\beta_{3}^{\prime} X_{i, t s}+\theta_{1} \text { cont }_{i, t s}+\lambda_{3}^{\prime} S_{t s}+\eta_{3}^{\prime} \text { state }_{s}+\delta_{3}^{\prime} \text { year }_{t}+u_{3 i, t s} \geq 0\right\}
$$

where cont $_{i, t s}$ denotes the amount of donation given by household $i$. If the amount of charitable contributions are independent of the unobservable factors that are correlated with the probability of political giving, then the above model can be estimated using a simple probit estimator. Otherwise, one must address the endogeneity of the amount of charitable contributions using instrumental variables. As in the bivariate probit model, I use price $e_{i, t s}$ as an instrument for the amount of charitable contributions. Hence, the reduced form model for the amount charitable contributions can be written as

$$
\text { cont }_{i, t s}=\beta_{4}^{\prime} X_{i, t s}+\zeta_{2} \text { price }_{i, t s}+\lambda_{4}^{\prime} S_{t s}+\eta_{4}^{\prime} \text { state }_{s}+\delta_{4}^{\prime} \text { year }_{t}+u_{4 i, t s} .
$$

Suppose that the error terms in eqs [3] and [4] are independently and identically distributed with a bivariate normal distribution with $E\left[\varepsilon_{3 i, t s}\right]=E\left[\varepsilon_{4 i, t s}\right]=0$, $\operatorname{var}\left[\varepsilon_{3 i, t s}\right]=1$ and $\operatorname{var}\left[\varepsilon_{4 i, t s}\right]=\sigma^{2}$. If $\varepsilon_{3 i, t s}$ and $\varepsilon_{4 i, t s}$ are correlated, then separate probit and ordinary least squares (OLS) estimation of the equations in [3] and [4] yields inconsistent estimates for the parameter vectors. In this case, the joint system of eqs [3] and [4] corresponds to the IV-Probit model as discussed in Wooldridge (2002) and can be estimated using the maximum-likelihood (ML) methodology.

\subsection{The effect of charitable behavior on the amount of political contributions}

In order to investigate the effect of the probability of giving to charitable organizations on the amount donated to political organizations, I consider the

However, Wilde (2000) argues that the joint model is identified as soon as both equations have a varying exogenous regressor. Monfardini and Radice (2008) also state that identification of this model does not require any additional instruments. But note that in the absence of exclusionary restrictions, identification relies heavily on the functional form. Therefore, estimation with additional instruments yields parameter estimates that are more robust to distributional misspecification. Hence, I rely on identifying instruments in the empirical analysis. 
following Tobit-type model which takes into account of a large group of individuals who do not donate to political organizations:

$$
\text { pcont }_{i, t s}=\max \left\{\mathbf{0}, \beta_{5}^{\prime} X_{i, t s}+\alpha_{2} \text { give }_{i, t s}+\lambda_{5}^{\prime} S_{t s}+\eta_{5}^{\prime} \text { state }_{s}+\delta_{5}^{\prime} \text { year }_{t}+u_{5 i, t s}\right\}
$$

where pcont $_{i, t s}$ denotes the amount of political contributions donated by household $i$. The causal effect of the probability of giving on the amount of political contributions can be consistently estimated using a Tobit model as long as $u_{5 i, t s}$ and give $e_{i, t s}$ are uncorrelated. In order to address the possible endogeneity of the probability of giving in the above equation, I also estimate a two-step endogenous Tobit model. In this model, following Angrist (2001), I first estimate eq. (2) and calculate a mills-ratio type endogeneity correction term

$$
\text { mills }=\text { give }_{i, t s}(-\phi / \Phi)+\left(1-\text { give }_{i, t s}\right) \phi /(1-\Phi)
$$

where $\phi$ and $\Phi$ are normal density and cumulative normal distribution functions evaluated at the probit first-stage fitted values. In the second stage, I estimate eq. [5] by including this correction term as an additional control variable. The coefficient of the correction term is $\varphi \sigma$, where $\varphi$ is the correlation between $u_{2 i, t s}$ and $u_{5 i, t s}$ and $\sigma$ is the standard deviation of the outcome residual. If this coefficient is significantly different from zero, then one should use a two-step endogenous Tobit model in order get a consistent effect of the probability of giving to charity on the amount of donations to political organizations.

Similarly, if the amount of charitable contributions are not correlated with the unobserved factors affecting the amount of political contributions, one can estimate the consistent effect of the amount of charitable contributions on the amount of political contributions using the following standard Tobit model ${ }^{23}$ :

$$
\text { pcont }_{i, t s}=\max \left\{\mathbf{0}, \beta_{6}^{\prime} X_{i, t s}+\theta_{2} \text { cont }_{i, t s}+\lambda_{6}^{\prime} S_{t s}+\eta_{6}^{\prime} \text { state }_{s}+\delta_{6}^{\prime} \text { year }_{t}+u_{6 i, t s}\right\} .
$$

Under the assumption that $u_{4 i, t s}$ and $u_{6 i, t s}$ are zero-mean normally distributed, if these two error terms are correlated, then the joint system of eqs [4] and [7] corresponds to the IV-Tobit model as discussed in Wooldridge (2002) and can be estimated using ML methodology.

23 An alternative to standard Tobit model is Censored Least Absolute Deviation (CLAD). However, Wilhelm (2008) shows that CLAD and Tobit models generate similar estimates in the context of charitable giving. 


\subsection{The validity of instruments}

In order to be a valid instrument, the tax price of giving should satisfy two conditions. First, it must be a determinant of the probability of giving and the amount of contributions to charitable organizations. Second, it must be uncorrelated with the unobservable covariates which might affect political giving. It is easy to check that the first condition is satisfied. The results presented in Appendix B show that the coefficient on the tax price of giving in the firststage regressions for alternative models is negative and in general, significant at conventional significance levels which suggests that people tend to give less to charities as giving becomes more expensive.

Thus, the credibility of parameter estimates depends on whether the second condition is fulfilled. I recognize that it is not possible to test directly whether this condition is satisfied. Since several determinants of the tax price such as income and number of children are already controlled for, the second condition may be violated if those who are more or less inclined to give to political organizations tend to sort themselves to certain tax brackets. This is highly unlikely since political contributions are not tax deductible and hence, they must be independent of the marginal tax rates. However, I address this possibility by investigating some observed characteristics of individuals who belong to different tax brackets. These characteristics are likely to reveal some unobserved aspects of political giving. For example, if some individuals are more likely to give to political organizations, then it is likely that these individuals have confidence in political parties. A unique question in the SGV contains information on each respondent's degree of confidence in political parties. ${ }^{24}$ Using this information, I find that respondents' confidence in political parties is independent of the tax bracket that they belong to. For example, those who are in 15\% tax bracket are almost equally likely to have the same confidence level compared with those who belong to $28 \%, 31 \%$, and $36 \%$ tax brackets (3.4 compared with 3.3, 3.4, and 3.6 respectively). Furthermore, in the 2001 wave of the SGV, respondents were also asked about their confidence in congress. The relationship between this variable and the tax price is comparable to those between confidence in political parties and the tax price, which suggests that the tax price is not correlated with the unobserved covariates that may affect political giving.

24 The respondents were asked the following question: "How much confidence you have in political parties?". The answers are coded as follows: "1-Great deal, 2-Quite a lot, 3-Some, 4-Very little". This question was not asked in 1990 survey year. 


\section{Results}

I start with estimating the relationship between the probabilities of giving to charitable and political organizations using probit and biprobit models. Probit models assume that the probability of giving to charitable organizations is exogenously determined, whereas biprobit models explicitly control for the potential endogeneity of the probability of giving to charitable organizations by using the tax price of giving as an instrument in the first stage. The results from the main models presented in the first specification of Table 3 show that probit and biprobit models yield similar results and imply that for the full sample, charitable donors are on average 7.4-8.1 percentage points more likely to give to political organizations compared with non-donors. Specifications $2-4$ in Table 3 report the results of the sensitivity tests performed to determine whether the estimated effect of the probability of charitable giving is robust to selection of the sample based on survey years, inclusion of alternative control variables, and using alternative instrumental variables. I also report results from separate regressions for unmarried respondents in the fifth specification. The

Table 3: The effect of the probability of giving to charitable organizations on the probability of giving to political organizations

\begin{tabular}{|c|c|c|c|c|}
\hline & \multirow[t]{2}{*}{ Number of obs. } & \multirow{2}{*}{$\frac{\text { Probit }}{\text { Marginal effect }}$} & \multicolumn{2}{|r|}{ Biprobit } \\
\hline & & & Marginal effect & Rho \\
\hline 1. Main model & 12,049 & $\begin{array}{c}0.074 \\
(0.007)^{\star \star \star}\end{array}$ & $\begin{array}{c}0.081 \\
(0.006)^{\star \star \star}\end{array}$ & $\begin{array}{l}-1.048 \\
(0.502)^{\star *}\end{array}$ \\
\hline 2. Additional controls & 11,081 & $\begin{array}{c}0.077 \\
(0.008)^{\star \star \star}\end{array}$ & $\begin{array}{r}0.053 \\
(0.041)\end{array}$ & $\begin{array}{r}0.124 \\
(0.346)\end{array}$ \\
\hline 3. Exclude 2001 & 8,241 & $\begin{array}{c}0.073 \\
(0.008)^{\star \star \star}\end{array}$ & $\begin{array}{c}0.074 \\
(0.005)^{\star \star \star}\end{array}$ & $\begin{array}{l}-1.012 \\
(0.515)^{\star \star}\end{array}$ \\
\hline 4. Alternative instruments & 12,049 & - & $\begin{array}{c}0.079 \\
(0.005)^{\star \star \star}\end{array}$ & $\begin{array}{l}-0.895 \\
(0.354)^{\star \star}\end{array}$ \\
\hline 5. Unmarried & 4,490 & $\begin{array}{c}0.048 \\
(0.007)^{\star \star \star}\end{array}$ & $\begin{array}{c}0.024 \\
(0.007)^{\star \star \star}\end{array}$ & $\begin{array}{l}-1.619 \\
(0.769)^{\star \star}\end{array}$ \\
\hline
\end{tabular}

Notes: For the probit models, marginal effects are calculated at the mean of the independent variables. For the bivariate probit models, marginal effects are calculated at the mean of the independent variables for the univariate probability of success, i.e. $\operatorname{Pr}($ Politics $=1)$ and $\operatorname{Pr}($ Give $=1)$. In addition to household-level control variables, all regressions include fixed year and state effects and state-level control variables as discussed in the text. Sample weights are used in all regressions. Robust standard errors are reported in parenthesis. The signs ** and $\star \star \star$ indicate that the estimate is significant at $5 \%$ and $1 \%$ significance levels, respectively. 
second specification adds three additional control variables to the probability of political giving and the first-stage probability of charitable giving equations. These variables control for the number of years that the household lived in their current community, whether the respondent attends religious services at least once a week as a proxy for household's religiosity, and whether the household owns their primary residence. ${ }^{25}$ I hypothesize that people who own their primary residence are more integrated into their communities and may be more likely to be influenced by the behavior of their neighbors. People may sort themselves to certain communities depending on community characteristics. If community characteristics are associated with political or charitable giving, then not controlling for these factors may yield biased estimates. Similarly, several studies have documented that religiosity is a significant determinant of charitable giving. If religiosity is also one of the determinants of political giving, then not controlling for this variable may significantly affect my results. However, in probit models, the marginal effect of the probability of charitable giving increases only 0.3 percentage points after these extra variables are controlled for. As mentioned before, until 2001, the Gallup Organization conducted biennial surveys of charitable giving and volunteering for Independent Sector. In 2001 Independent Sector hired Westat Inc. to conduct the same survey. As a result, in the 2001 wave of the survey series, the sample size increased considerably, some questions were dropped from the survey, and the wording of some others changed. In order to check whether these changes affect the estimation results, the third specification excludes this year from the sample. Excluding the 2001 subsample does not affect the marginal effect of the probability of charitable giving in probit and bivariate probit models. In the fourth specification, instead of using a continuous measure of the tax price of giving, I use a set of dummy variables that correspond to different tax brackets as instruments. ${ }^{26}$ Compared with the base bivariate probit model, in this specification, the marginal effect of the probability of giving to charitable organizations remains virtually the same. The last specification documents the relationship between the probabilities of charitable and political giving marital status. On average, unmarried charitable donors are 2.4-4.8 percentage points more likely to give to political organizations compared with unmarried non-donors.

25 The definition and summary statistics of these variables are presented in Appendix A.

26 These five dummy variables are generated for those who itemize deductions in their federal tax return and correspond to marginal tax rates of less than $15 \%, 15-28 \%, 28-31 \%, 31-36 \%$, and more than $36 \%$. The excluded category is those who do not itemize deductions. The coefficients on these dummy variables are significant in the first-stage regressions. These results are available from the author upon request. 
Table 4: The effect of the amount of charitable contributions on the probability of giving to political organizations

\begin{tabular}{lcccc}
\hline & Number of obs. & Probit & & IV-Probit \\
\cline { 3 - 3 } & & Marginal effect & & Marginal effect \\
\hline 1. Main model & 12,049 & 0.005 & 0.113 \\
& & $(0.002)^{\star \star}$ & $(0.031)^{\star \star \star}$ \\
2. Additional controls & 11,081 & 0.004 & 0.148 \\
3. Exclude 2001 & & $(0.002)^{\star \star}$ & $(0.060)^{\star \star}$ \\
& & 0.005 & 0.122 \\
4. Alternative instruments & 12,049 & $(0.002)^{\star \star}$ & $(0.035)^{\star \star \star}$ \\
5. Unmarried & & - & 0.042 \\
& 4,490 & & 0.014 & $0.016)^{\star \star \star}$ \\
& & $(0.004)^{\star \star \star}$ & $(0.051)$ \\
\hline
\end{tabular}

Notes: The estimated marginal effects and standard errors are multiplied by 1,000 . For the probit and IV-Probit models, marginal effects are calculated at the mean of the independent variables. In addition to household-level control variables, all regressions include fixed year and state effects and state-level control variables as discussed in the text. Sample weights are used in all regressions. Robust standard errors are reported in parenthesis. The signs $* \star$ and $\star \star \star$ indicate that the estimate is significant at $5 \%$ and $1 \%$ significance levels, respectively.

Table 4 documents the effect of the amount of charitable contributions on the probability of giving to political organizations. In order to make marginal effects easily interpretable, I multiply each estimate and its standard error by 1,000. The main probit model which assumes the exogeneity of the amount of charitable donations suggests that a $\$ 1,000$ increase in charitable contribution amount is associated with a 0.5 percentage point increase in the probability of giving to political organizations. The probit models in the second and third specifications yield virtually the same effect of the amount of charitable contributions on the probability of giving to political organizations. The marginal effect of the amount of charitable contributions is relatively larger for unmarried respondents (1.4 percentage points). Compared with the probit model, the main IV-Probit model estimated using the tax price of giving as an instrument suggests that the effect of the charitable contribution amount on the probability of giving to political organizations is larger. In particular, this model shows that a $\$ 1,000$ increase in contribution amount is associated with a 11.3 percentage point increase in the probability of giving to political organizations. A similar result also prevails once the additional controls are included in the model or the 2001 survey year is excluded from the sample. However, the IV-Probit model yields a relatively smaller impact when a set of dummy variables that 
correspond to different tax brackets are used as instruments in the first stage. This model suggests that the probability of giving to political organizations increases by 4.2 percentage points as a response to a $\$ 1,000$ increase in charitable contributions.

In Table 5, I report the marginal effect of the probability of giving to charitable organizations on the amount of political contributions. Compared with the single equation Tobit models, the IV-Tobit models which control for the endogeneity of the probability of charitable giving yield a larger impact of the probability of charitable giving on the amount of political contributions. The main Tobit model shows that compared with non-donors, donors on average give $\$ 74$ more to political organizations, whereas the IV-Tobit model suggests that compared with non-donors, charitable donors give $\$ 122$ more to political organizations. A similar result also observed once the 2001 survey year is excluded from the sample or alternative instruments are used in the first stage of the IV-Tobit model. However, results from the second specification imply that the estimated impact of being a charitable donor on the amount of political contributions is statistically insignificant in the IV-Tobit model once the additional control variables are included to the model. As in other models, the last specification in Table 5 shows that the effect of being a charitable donor on the

Table 5: The effect of the probability of giving to charitable organizations on the amount of political contributions

\begin{tabular}{|c|c|c|c|c|}
\hline & \multirow[t]{2}{*}{ Number of obs. } & \multirow{2}{*}{$\frac{\text { Tobit }}{\text { Marginal effect }}$} & \multicolumn{2}{|r|}{ IV-Tobit } \\
\hline & & & Marginal effect & Mills ratio \\
\hline 1. Main model & 12,065 & $\begin{array}{c}73.764 \\
(20.744)^{\star \star \star}\end{array}$ & $\begin{array}{l}122.166 \\
(42.077)^{\star \star \star}\end{array}$ & $\begin{array}{r}239.117 \\
(175.183)\end{array}$ \\
\hline 2. Additional controls & 11,097 & $\begin{array}{c}90.912 \\
(26.594)^{\star \star \star}\end{array}$ & $\begin{array}{r}47.224 \\
(50.308)\end{array}$ & $\begin{array}{l}-206.957 \\
(258.874)\end{array}$ \\
\hline 3. Exclude 2001 & 8,284 & $\begin{array}{c}73.451 \\
(20.927)^{\star \star \star}\end{array}$ & $\begin{array}{l}129.955 \\
(43.766)^{\star \star \star}\end{array}$ & $\begin{array}{r}280.008 \\
(188.958)\end{array}$ \\
\hline 4. Alternative instruments & 12,065 & - & $\begin{array}{l}130.841 \\
(44.317)^{\star \star \star}\end{array}$ & $\begin{array}{r}284.559 \\
(184.040)\end{array}$ \\
\hline 5. Unmarried & 4,562 & $\begin{array}{l}22.071 \\
(5.836)^{\star \star \star}\end{array}$ & $\begin{array}{c}42.655 \\
(18.237)^{\star \star}\end{array}$ & $\begin{array}{r}116.402 \\
(93.945)\end{array}$ \\
\hline
\end{tabular}

Notes: For the Tobit and IV-Tobit models, marginal effects are calculated for the expected value of the dependent variable conditional on being uncensored, i.e. $E(\ln (p \operatorname{cont}) \mid 0<\ln ($ pcont $))$. In addition to household-level control variables, all regressions include fixed year and state effects and state-level control variables as discussed in the text. Sample weights are used in all regressions. Robust standard errors are reported in parenthesis. The signs $* \star$ and $* \star *$ indicate that the estimate is significant at $5 \%$ and $1 \%$ significance levels, respectively. 
amount of contributions to political organizations is relatively smaller for unmarried respondents.

Table 6 documents the relationship between charitable and political contributions. The main Tobit model suggests that a one dollar increase in the amount of charitable donations is associated with a 0.005 dollar increase in the amount of political contributions. However, the IV-Tobit model which controls for the potential endogeneity of charitable contributions suggests that a one dollar increase in charitable contributions increases political contributions by 0.15 dollars. These estimates are significant at conventional significance levels. Specifications 2 and 3 show that this result is robust to the inclusion of additional controls or exclusion of the 2001 survey year from the sample. The fourth specification of Table 6 shows that the effect of the amount of charitable contributions on the amount of political contributions remains positive when alternative instruments are used in the first stage of the IV-Tobit model. However, this effect is not statistically significant. The last specification shows that for unmarried respondents, a one dollar increase in charitable contributions is associated with a 0.006 dollar increase in the amount of political contributions.

Table 6: The effect of the amount of charitable contributions on the amount of political contributions

\begin{tabular}{lcccc}
\hline & Number of obs. & Tobit & & IV-Tobit \\
\cline { 3 - 4 } & & Marginal effect & & Marginal effect \\
\hline 1. Main model & 12,065 & 0.005 & 0.149 \\
2. Additional controls & & $(0.003)^{\star}$ & $(0.072)^{\star \star}$ \\
& 11,097 & 0.005 & 0.199 \\
3. Exclude 2001 & & $(0.003)^{\star}$ & $(0.169)$ \\
& & 0.005 & 0.141 \\
4. Alternative instruments & 12,065 & $(0.003)^{\star}$ & $(0.072)^{\star \star}$ \\
5. Unmarried & & - & 0.038 \\
& 4,562 & & 0.006 & $0.027)$ \\
& & $(0.002)^{\star \star \star}$ & 0.006 \\
\end{tabular}

Notes: For the Tobit and IV-Tobit models, marginal effects are calculated for the expected value of the dependent variable conditional on being uncensored, i.e. $E(\ln ($ pcont $) \mid 0<\ln (p c o n t))$. In addition to household-level control variables, all regressions include fixed year and state effects and state-level control variables as discussed in the text. Sample weights are used in all regressions. Robust standard errors are reported in parenthesis. The signs *, ** and *** indicate that the estimate is significant at $10 \%, 5 \%$ and $1 \%$ significance levels, respectively. 
In general, compared with probit and Tobit models, IV-Probit and IV-Tobit models consistently produce larger effects of charitable giving on political contributions. This result is counterintuitive in a sense that if people who donate more to charity are also those who are more likely to give to political organizations, then not controlling for the endogeneity of the amount of charitable contributions would lead one to overestimate the true relationship between the amount given to charity and political organizations rather than to underestimate it. How can one justify the fact that some unobservable covariates that have a positive impact on charitable giving has a negative effect on political contributions? The public agenda changes as public priorities shift. The empirical models do not control for several events that may directly affect the public agenda. For instance, as the intensity of news about the political parties and organizations increases during the election years, political activities such as contributions of time and money for political organizations and the propensity to vote are expected to increase, whereas people may shy away from other prosocial behaviors such as charitable giving. Similarly, the media has the power to encourage generosity. The media coverage of humanitarian crises or natural disasters is positively associated with charitable giving. ${ }^{27}$ As the public priorities tend to shift toward charitable giving aftermath of such events, political giving may be negatively affected. Yet, I also recognize that none of these hypotheses are testable due to the limitations of the survey data. ${ }^{28}$

\section{The spillover effects of charitable subsidies on political giving}

The above analysis clearly shows the positive relationship between charitable and political giving. Policymakers in the Unites States and many other countries

27 Brown and Minty (2008) document the positive effect of media on charitable giving. Yörük (2008, 2012a, 2012b) documents the positive effect of information and media campaigns on volunteering. Gerber, Karlan, and Bergan (2009) investigate the effect of newspapers on voting behavior and political options.

28 Another possible reason for the negative correlation between the error terms of the charitable and political giving equations might be the attenuation bias caused by the measurement error in different measures of charitable giving. In particular, the survey literature generally reports that respondents' answers on attitudinal questions are subject to measurement error. However, IV-Probit and IV-Tobit models estimated by appropriate instruments should correct for the measurement error provided that the instruments are correlated with the true value of charitable giving and not with the measurement error. 
encourage charitable giving through various subsidies. In the United States, for instance, charitable contributions can be deducted from taxable income making the price of giving inversely related to the marginal tax rate. In this section, I investigate the spillover effect of these policies by focusing on the relationship between the tax price of giving and political contributions.

Using eqs [1] and [2], one can write down a reduced form equation of the probability of giving to political organizations as a function of observable covariates and the tax price of giving. This model would be similar to eq. [2] except that the outcome variable is politics instead of give. Since political contributions are not tax deductible, the tax price of giving is exogenous in this reduced form equation and therefore its effect on the probability of giving to political organizations can be consistently estimated using a simple probit model.

Estimating this reduced form model, I find that charitable and political giving are complements. Increasing the tax price of giving not only decreases the predicted probability of charitable giving but also decreases the predicted probability of political giving. Figure 2 documents this finding for the full

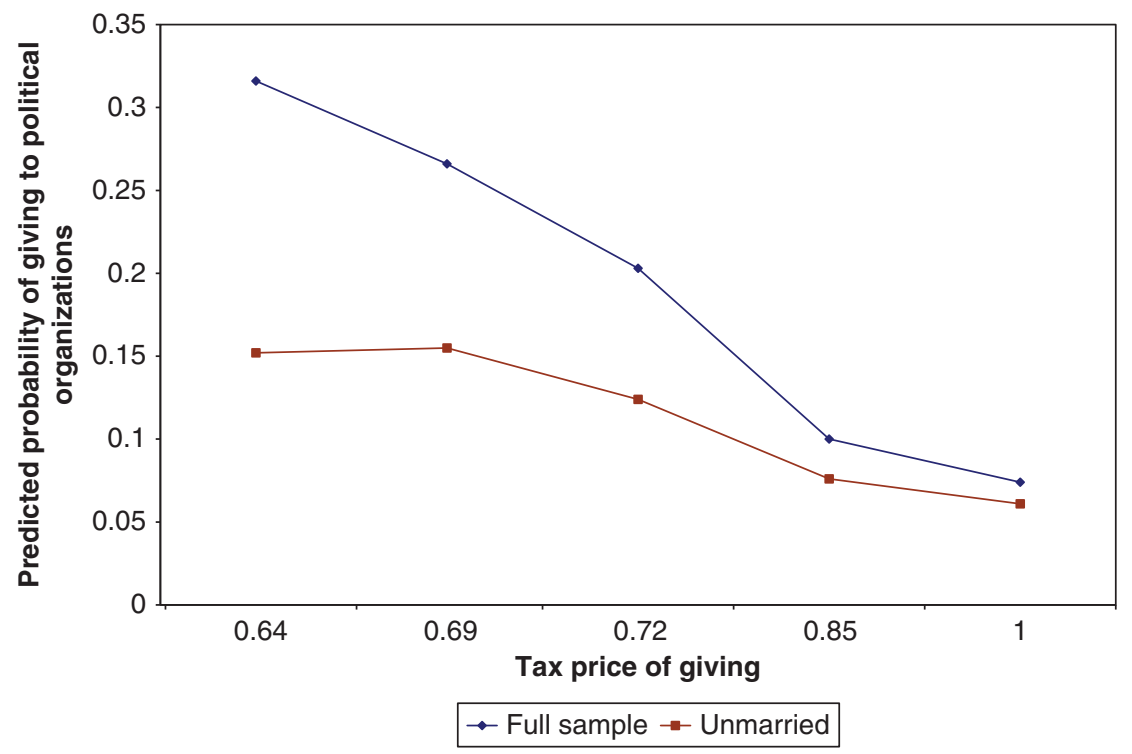

Figure 2: Predicted probability of giving to political organizations by the tax price of giving Note: The predicted probabilities are calculated from reduced form probit models as discussed in the text. 
sample and for the unmarried respondents. At the highest tax bracket, a charitable contribution of one dollar costs only 64 cents to a donor whose predicted probability of political contribution is 0.32 . When the cost of donating a dollar to charity rises to 85 cents, the predicted probability of giving to a political organization decreases to 0.1 . If charitable donors do not itemize their contributions in their tax return, then the effective price of giving is unity. At this price, charitable contributions are not subsidized and the probability of giving to political organizations decreases to 0.07 . The relationship between the predicted probability of political giving and tax price is also robust to selection of sample based on marital status.

Using eqs [4] and [7], I derive a similar reduced form equation of the amount of political contributions as a function of control variables and the tax price of giving. I estimate this model using a Tobit estimator and calculate the elasticity of the amount of political contributions with respect to the tax price of giving. The results presented in Figure 3 show that at the tax price of 0.64 , a $1 \%$ increase in the tax price of giving decreases the amount donated to a

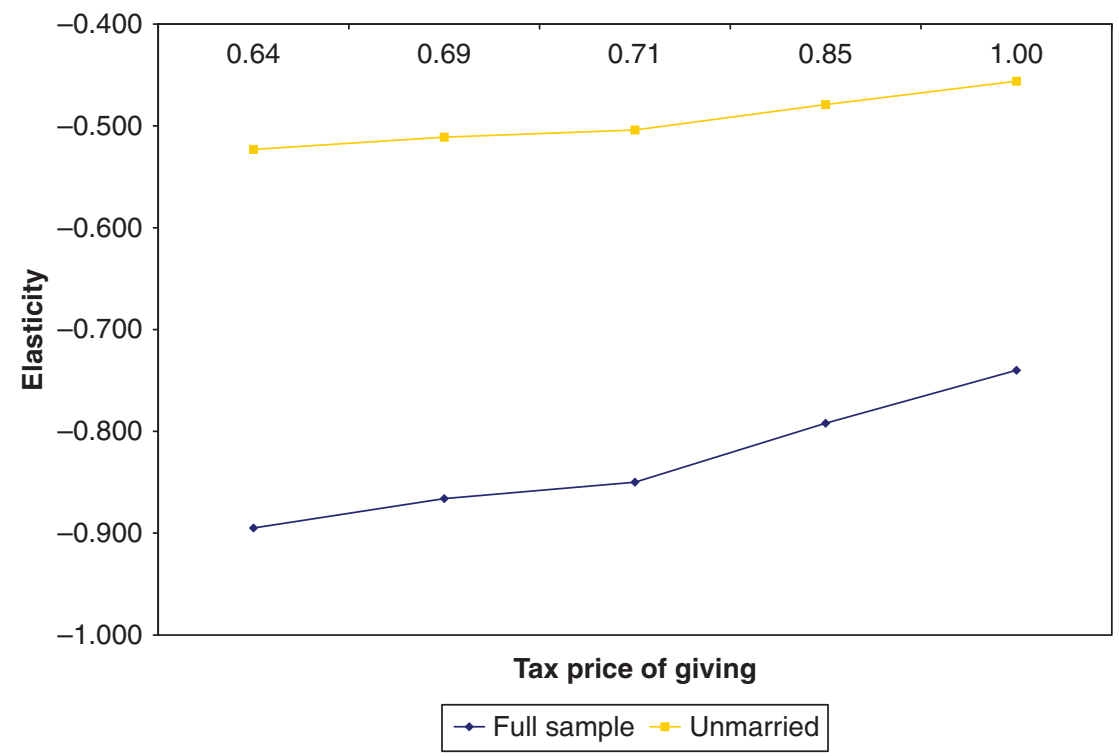

Figure 3: Elasticity of the amount of political contributions with respect to the tax price of giving Note: Cross-price elasticities are calculated from reduced form Tobit models as discussed in the text. 
political organization by $0.89 \%$. This estimated elasticity is also statistically significant $(p-$ value $=0.001)$. The cross-price elasticity of the amount of political contributions goes up as the tax price increases. At the lowest tax bracket (15\%), the implied cross-price elasticity of the amount of political contributions is $-0.79(p-$ value $=0.000)$. When the tax price is unity, a one percentage point increase in the tax price corresponds to a $0.74 \%$ decrease in the amount of political contributions $(p-$ value $=0.000)$. The estimated cross-price elasticities for unmarried respondents are smaller compared with the full sample. For example, at the tax price of 0.85 , unmarried respondents tend to decrease the amount of their political contributions by $0.47 \%$ as a response to a $1 \%$ increase in the tax price of giving ( $p-$ value $=0.102)$. These results highlight the externalities created by charitable subsidies on political giving and may help policymakers to make informed choices about the indirect effects of charitable subsidies on other types of contributions that are not tax deductible.

\section{Conclusion}

Policymakers promote tax reliefs for charitable donors who itemize their donations in their federal and state tax returns. However, the existing literature focuses on the immediate effect of such policies on charitable contributions and often ignores their impact on other types of contributions that are not tax deductible. In this paper, I focus on a particular type of contributions that are not tax deductible, namely political contributions. I explore the relationship between charitable and political contributions and investigate the spillover effects of charitable subsidies on political giving using five cross-sectional surveys of charitable and political giving in the United States conducted from 1990 to 2001.

I document that charitable and political giving are positively associated. Controlling for the endogeneity of charitable behavior in political giving models, I find that compared with non-donors, charitable donors are on average 7.4-8.1 percentage points more likely to give to political organizations. Charitable donors also donate more to political organizations compared with their nondonor peers even after income and other observable characteristics are controlled for. I also find a positive relationship between the amount of gifts donated to charitable and political organizations. A one dollar increase in 
charitable contributions increases political contributions by 0.15 dollars. Furthermore, the relationship between charitable and political giving is robust under different specifications.

I find that compared with single equation models, models that control for the endogeneity of the amount of charitable contributions yield a larger effect of charitable contributions on political giving. This result is quite surprising since one might expect to find a positive relationship between the unobserved factors that jointly affect charitable and political giving. For instance, if people who are more charitably inclined are also those who are more likely to give to political organizations, then not controlling for the endogeneity of charitable behavior would lead one to overestimate the true relationship between charitable and political giving rather than to underestimate it. I propose several arguments that may explain the counterintuitive results. In particular, I argue that several events that may directly affect the public agenda, an unobserved covariate in empirical models, might be positively associated with charitable contributions but might have a negative effect on political giving or vice versa.

Estimating reduced form models of political giving, I find that charitable and political giving are complements at different tax price levels. Hence, policies that encourage charitable giving have positive spillover effects on the political contributions. This effect gets relatively smaller as the tax price of giving goes up. I find that at the tax price of 0.64 , the implied cross-price elasticity of the amount of political contributions is -0.89 . However, when the tax price is unity, a one percentage point increase in the tax price corresponds to a $0.74 \%$ decrease in the amount of political contributions. Furthermore, the estimated cross-price elasticities unmarried respondents are smaller compared with the full sample.

This paper documents a previously ignored relationship between charitable and political giving. It also highlights the externalities created by charitable subsidies and provides insights for alternative theoretical models which may investigate the indirect effects of charitable subsidies on different types of contributions and prosocial behaviors. However, it cannot explore several related questions mostly due to the limitations of the survey data. For example, Hinich (1981) develops a model to examine choices of voting or contributing to political parties. A similar relationship may exist between charitable giving and other types of prosocial behavior. Although this paper argues that charitable giving and other prosocial behaviors might be correlated, further research is needed to explore this possible relationship. 


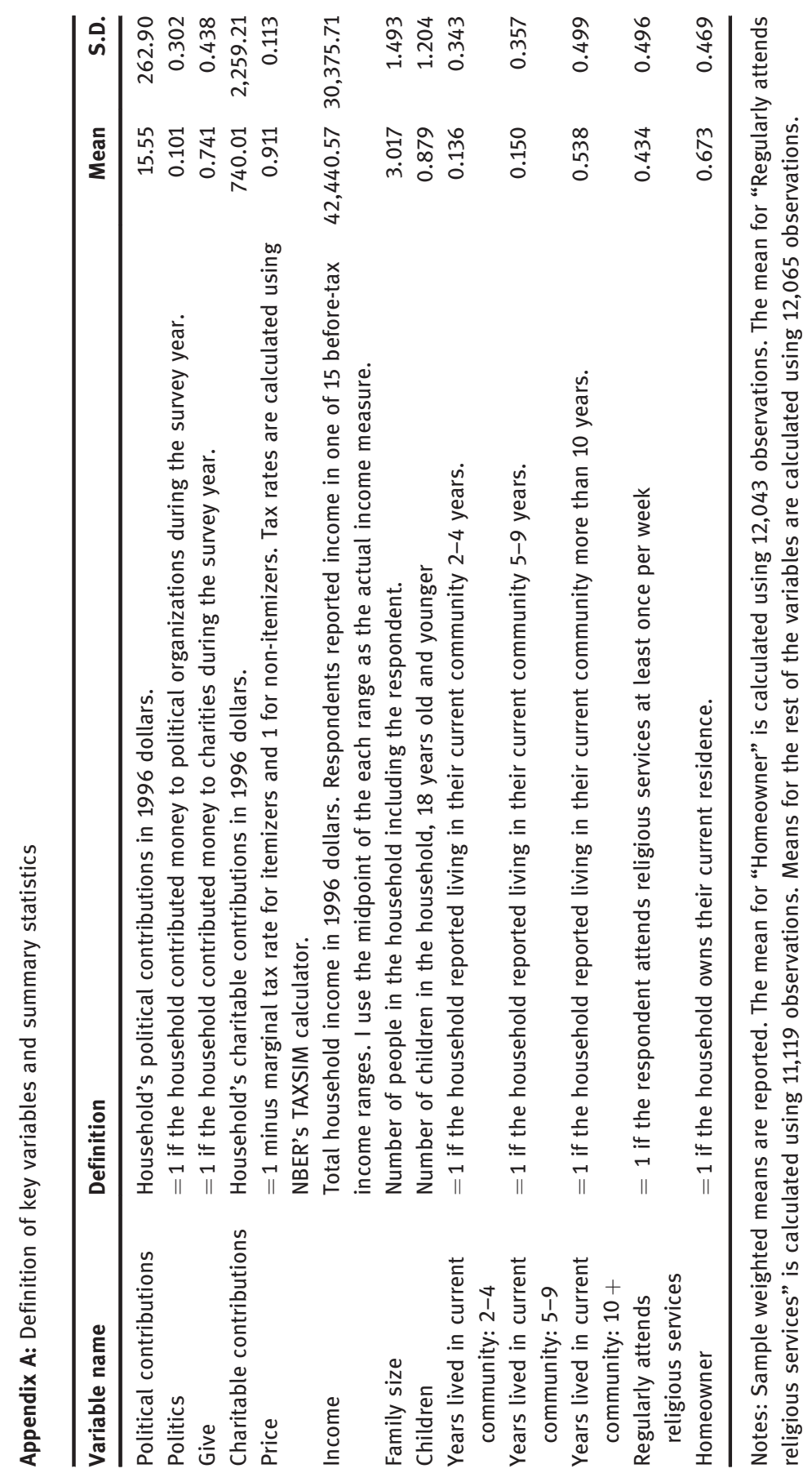


Appendix B: The effect of the tax price of giving on charitable contributions: First-stage regressions for alternative models

\begin{tabular}{lllll}
\hline & \multicolumn{1}{c}{$(1)$} & \multicolumn{1}{c}{ (2) } & \multicolumn{1}{c}{ (3) } \\
\hline Main model & -0.519 & -957.678 & -0.548 & -957.423 \\
& $(0.090)^{\star \star \star}$ & $(362.492)^{\star \star \star}$ & $(0.064)^{\star \star \star}$ & $(358.245)^{\star \star \star}$ \\
Additional controls & -0.358 & -564.321 & -0.370 & -564.024 \\
& $(0.062)^{\star \star \star}$ & $(439.471)$ & $(0.058)^{\star \star \star}$ & $(426.943)$ \\
Exclude 2001 & -0.548 & -907.889 & -0.576 & -907.762 \\
& $(0.091)^{\star \star \star}$ & $(385.481)^{\star \star}$ & $(0.068)^{\star \star \star}$ & $(381.514)^{\star \star}$ \\
Unmarried & -0.548 & $-1,025.188$ & -0.701 & $-1,025.179$ \\
& $(0.170)^{\star \star \star}$ & $(287.572)^{\star \star \star}$ & $(0.118)^{\star \star \star}$ & $(285.195)^{\star \star \star}$ \\
\hline
\end{tabular}

Notes: All regressions include fixed year and state effects and household-level control variables as discussed in the text. Sample weights are used in all regressions. Robust standard errors are reported in parenthesis. The signs ** and *** represent statistical significance at $5 \%$ and $1 \%$ significance level, respectively. Specification (1): The marginal effect of $\ln$ (Price) on the propensity to give in bivariate probit models is reported for alternative models. Marginal effects are reported for the univariate probability of success, i.e., $\operatorname{Pr}($ Give $=1)$. This is the first-stage regression results for bivariate probit models reported in Table 3. Specification (2): The coefficient estimate for the effect of $\ln$ (Price) on charitable contributions is reported for alternative models. This is the first-stage regression results for IV-Probit models reported in Table 4. Specification (3): The marginal effect of $\ln$ (Price) on the propensity to give in probit models is reported for alternative models. This is the first-stage regression results for IV-Tobit models reported in Table 5. Specification (4): The coefficient estimate for the effect of $\ln$ (Price) on charitable contributions is reported for alternative models. This is the first-stage regression results for IV-Tobit models reported in Table 6.

\section{References}

Abler, D. G. 1991. "Campaign Contributions and House Voting on Sugar and Dairy Legislation." American Journal of Agricultural Economics 73:11-17.

Amaro-de-Matos, J., and P. Barros. 2004. "Social Norms and the Paradox of Elections' Turnout." Public Choice 121:239-55.

Andreoni, J. 2006. "Philanthropy." In Handbook of Giving, Reciprocity and Altruism, edited by S.-C. Kolm and J. Mercier Ythier, 1201-69. Amsterdam: North Holland.

Andreoni, J., E. Brown, and I. Rischall. 2003. "Charitable Giving by Married Couples: Who Decides and Why Does It Matter?" Journal of Human Resources 38:111-33.

Andreoni, J. E., W. G. Gale, and J. K. Scholz. 1996. "Charitable Contributions of Time and Money." Unpublished Manuscript, University of Wisconsin.

Angrist, J. D. 2001. "Estimation of Limited Dependent Variable Models with Dummy Endogenous Regressors: Simple Strategies for Empirical Practice." Journal of Business and Economic Statistics 19:2-16. 
Auten, G., H. Sieg, and C. T. Clotfelter. 2002. "Charitable Giving, Income, and Taxes: An Analysis of Panel Data." American Economic Review 92:371-82.

Brown, E., and H. Lankford. 1992. "Gifts of Money and Time: Estimating the Effects of Tax Prices and Available Time." Journal of Public Economics 47:321-41.

Brown, P. H., and J. H. Minty. 2008. "Media Coverage and Charitable Giving After the 2004 Tsunami." Southern Economic Journal 75:9-25.

Clotfelter, C. T. 1990. "The Impact of Tax Reform on Charitable Giving: A 1989 Perspective." In Do Taxes Matter? The Impact of the Tax Reform Act of 1986, edited by J. Slemrod. Cambridge: MIT Press.

Cooper, M. J., H. Gulen, and A. V. Ovtchinnikov. 2010. "Corporate Political Contributions and Stock Returns.” Journal of Finance 65:687-724.

Copeland, C., and D. Laband. 2002. "Expressiveness and Voting." Public Choice 110:351-63.

de Figueiredo, R. J., and G. Edwards. 2007. "Does Private Money Buy Public Policy? Campaign Contributions and Regulatory Outcomes in Telecommunications." Journal of Economics \& Management Strategy 16:547-76.

Denny, K., and O. Doyle. 2008. "Political Interest, Cognitive Ability and Personality: Determinants of Voter Turnout in Britain." British Journal of Political Science 38:291-310.

Duncan, B. 1999. "Modeling Charitable Contributions of Time and Money." Journal of Public Economics 72:213-42.

Evans, W. N., and R. M. Schwab. 1995. "Finishing High School and Starting College: Do Catholic Schools Make a Difference?" Quarterly Journal of Economics 110:941-74.

Feldman, N. E. 2010. “Time Is Money: Choosing Between Charitable Activities.” American Economic Journal: Economic Policy 1:103-30.

Ferris, J. 1998. "The Role of the Nonprofit Sector in a Self-Governing Society: The View from the United States." Voluntas 9:137-51.

Gerber, A. S., D. Karlan, and D. Bergan. 2009. "Does the Media Matter? A Field Experiment Measuring the Effect of Newspapers on Voting Behavior and Political Opinions." American Economic Journal: Applied Economics 1:35-52.

Gruber, J. 2004. "Pay or Pray? The Impact of Charitable Subsidies on Religious Attendance." Journal of Public Economics 88:2635-55.

Gruber, J., and E. Saez. 2002. "The Elasticity of Taxable Income: Evidence and Implications." Journal of Public Economics 84:1-32.

Hinich, M. J. 1981. "Voting as an Act of Contribution." Public Choice 36:135-40.

Joint Committee on Taxation. 2013. "Estimates of Federal Tax Expenditures for Fiscal Years 2012-2017." U. S. Government Printing Office, Washington, DC.

Joulfaian, D., and M. L. Marlow. 1991. "Incentives and Political Contributions." Public Choice 69:351-55.

Maddala, G. S. 1983. Limited Dependent and Qualitative Variables in Econometrics. Cambridge, UK: Cambridge University Press.

Menchik, P., and B. A. Weisbrod. 1987. "Volunteer Labor Supply." Journal of Public Economics 32:159-83.

Monfardini, C., and R. Radice. 2008. "Testing Exogeneity in the Bivariate Probit Model: A Monte Carlo Study." Oxford Bulletin of Economics and Statistics 70:271-82.

Randolph, W. C. 1995. "Dynamic Income, Progressive Taxes, and the Timing of Charitable Contributions." Journal of Political Economy 103:709-38.

Roberts, R. D. 1987. "Financing Public Goods.” Journal of Political Economy 95:420-37. 
Saez, E. 2004. "The Optimal Treatment of Tax Expenditures." Journal of Public Economics 88:2657-84.

Sullivan, D. 1985. "Simultaneous Determination of Church Contributions and Church Attendance." Economic Inquiry 23:309-20.

Twenge, J. M., R. F. Baumeister, C. N. DeWall, N. J. Ciarocco, J. M. Bartels. 2007. "Social Exclusion Decreases Prosocial Behavior." Journal of Personality and Social Psychology 92:56-66.

Weisbrod, B. 1988. The Nonprofit Economy. Cambridge, MA: Harvard University Press.

Wilde, J. 2000. "Identification of Multiple Equation Probit Models with Endogenous Dummy Regressors." Economics Letters 69:309-12.

Wilhelm, M. 2008. "Practical Considerations for Choosing Between Tobit, SCLS or CLAD Estimators for Censored Regression Models with an Application for Charitable Giving." Oxford Bulletin of Economics and Statistics 70:559-82.

Wooldridge, J. M. 2002. Econometric Analysis of Cross Section and Panel Data. Cambridge, MA: MIT Press.

Yörük, B. K. 2008. "The Power of Asking in Volunteering: Evidence From a Matched Sample.” Economics Letters 99:79-84.

Yörük, B. K. 2009. “How Responsive Are Charitable Donors to Requests to Give?” Journal of Public Economics 93:1111-17.

Yörük, B. K. 2010. “Charitable Giving by Married Couples Revisited." Journal of Human Resources 45:497-516.

Yörük, B. K. 2012a. "The Effect of Media on Charitable Giving and Volunteering: Evidence from the 'Give Five' Campaign.” Journal of Policy Analysis and Management 31:813-36.

Yörük, B. K. 2012b. "Do Charitable Solicitations Matter?: A Comparative Analysis of Fundraising Methods." Fiscal Studies 33:467-87.

Yörük, B. K. 2013. "The Impact of Charitable Subsidies on Religious Giving and Attendance: Evidence from Panel Data." Review of Economics and Statistics 95:1708-21. 